apuntesuniversitarios.upeu.edu.pe

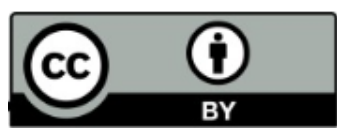

Apuntes Universitarios, 2020: 10(3), julio-setiembre

ISSN: 2304-0335 DOI: https://doi.org/10.17162/au.v10i3.479

\title{
Algunos problemas prácticos de traducción relacionados con el concepto de "traducción filológica" (en el ejemplo de la traducción de las obras de C. Simon del francés al ruso)
}

\section{Some practical translation problems related to the concept of "philological translation" (on the example of the translation of C. Simon's works from French to Russian)}

\author{
Vishnyakov A. G. ${ }^{1 \text { a }}$, Kasatkina O. A. ${ }^{2}$, Maslechkina S. V. ${ }^{3}$, Filatova N. A. ${ }^{4}$, Ivanova N. A. ${ }^{5}$
}

State University of Humanities and Technology, Russia ${ }^{12345}$

Orcid ID: https://orcid.org/0000-0001-5906-98601

Orcid ID: https://orcid.org/0000-0002-2409-9354 ${ }^{2}$

Orcid ID: https://orcid.org/0000-0002-0351-6956 3

Orcid ID: https://orcid.org/0000-0002-3386-47404

Orcid ID: https://orcid.org/0000-0001-6190-89695

Recibido: 03 de enero 2020

Aceptado: 09 de junio 2020

\begin{abstract}
Resumen
El propósito de este trabajo es presentar una hipótesis sobre la "traducción filológica" de textos literarios de mayor complejidad y probarla en el material de obras específicas. Basado en el material de los estudios de traducción rusa y extranjera, el documento formula el concepto de "traducción filológica" en el apéndice de un proyecto editorial específico dentro de la serie "Monumentos literarios" publicada por el Instituto de Literatura Mundial de la Academia de Ciencias de Rusia, y considera los aspectos prácticos más importantes del problema de la traducción adecuada de textos literarios de mayor complejidad. El análisis de la traducción de dos obras por el representante de la Nueva Novela francesa Claude Simon ilustra claramente el ejemplo de una "traducción filológica". En el curso del estudio, los autores llegaron a la conclusión de que una traducción filológica implica una apelación a un texto que es clásico en su riqueza, complejidad y significado en la literatura mundial. El potencial comercial de traducir un texto de este tipo no es obvio y requiere que el editor renuncie a la rentabilidad a corto plazo, que el traductor renuncie al trabajo de rutina que se ajusta a un marco de tiempo predeterminado y que el lector deje de centrarse en lo no problemático (no conflicto, sin complicaciones), lineal, lectura / consumo de una sola vez del libro a favor de volver a leer / saborear.
\end{abstract}

Palabras clave: traducción filológica, adecuación de la traducción literaria, "biblioteca de las Pléyades", "Monumentos literarios", Claude Simon, Nueva novela.

${ }^{\mathrm{a}}$ Correspondencia al autor 


\section{Abstract}

The purpose of this paper is to put forward a hypothesis about the "philological translation" of literary texts of increased complexity and test it on the material of specific works. Based on the material of Russian and foreign translation studies, this paper formulates the concept of "philological translation" in the appendix to a specific publishing project within the series "Literary monuments" published by the Institute of World Literature of the Russian Academy of Sciences, and considers the most important practical aspects of the problem of adequate translation of literary texts of increased complexity. The analysis of the translation of two works by the representative of the French New Novel Claude Simon illustrates clearly the example of a "philological translation". In the course of the study, the authors came to the conclusion that a philological translation implies an appeal to a text that is classical in its richness, complexity, and significance in world literature. The commercial potential of translating such a text is not obvious and requires the publisher to give up short-term profitability, the translator to give up routine work that fits into a predetermined time frame, and the reader to give up focusing on non-problematic (non-conflict, uncomplicated), linear, one-time reading/consumption of the book in favor of re-reading/savoring.

Keywords: philological translation, adequacy of literary translation, "library of the Pleiades", "Literary monuments", Claude Simon, New novel.

\section{Introduction}

In the modern world, where the number and complexity of translated texts is rapidly increasing, the problem of adequate translation of texts of increased complexity in general and literary texts in particular is becoming more and more urgent. The experience of the last decades has convincingly shown that it is impossible to solve this problem by using information and computer technologies alone. In this light, this study, which analyzes the problem of translation adequacy in its application to the most complex type of foreign language text, a literary text, is very relevant and useful for literary critics and linguists.

The scientific novelty consists in the introduction of a new concept of translation studies ("philological translation") and the experience of its practical application to the translation of specific literary texts. The object of the paper is the concept of "philological translation", and the subject is the application of this type of translation to the translation of Claude Simon's texts into Russian. The purpose of this paper is to put forward a hypothesis about the "philological translation" of literary texts of increased complexity and test it on the material of specific works.

\section{Materials and methods of research}

The research material was Simon's works "L'Herbe (The Grass)", "La Route des Flandres (The Flanders Road)", "L'Invitation (The Invitation)" and their translations into Russian, made by A. Vishnyakov (2015). The following methods were used during the study: historical and genetic method, typological method, comparative and historical method, method of theoretical poetics, hermeneutical and interpretative method.

Any attempts to classify in the humanitarian sphere, and in literary studies and translation studies in particular, are always vulnerable and hampered by the initial impossibility of reducing 
the source material (language and literary works in the original language or translation) to a mathematical "common denominator". Nevertheless, the desire to classify is irresistible in most humanitarians, what is described well by the French semiotician, who did it almost better than anyone, Gerard Genette, who believed that of the various forms of libido already known or still waiting to be discovered, libido classificandi and/or nominandi, is "the only one that can be considered absolutely legitimate" (Charles, 2019; 5).

In our opinion, many Russian-language and translated works require additional reference equipment in the form of comments, scientific papers about the author's epoch and poetics, etc. These additions are an integral part of the preparation and publication of a "philological translation" of a foreign language text.

\section{Results and discussion}

The method of "philological translation" in practice (on the example of the translation of C. Simon's works from French into Russian)

The volume of selected works by the French writer Claude Simon, which is being prepared for the Literary monuments series by one of the co-authors of this paper, will include two of his works - the novel "The Grass" ("L'herbe", 1958) and the 1988 work "The Invitation" ("L'invitation"). Consideration of the features of the first of these two texts is beyond the scope of this paper. Nevertheless, we note that this novel is characterized by a transitional, borderline situation - between the norm (language, genre, stylistic) and its violation, or even destruction, which is difficult to perceive and is perceived by native French speakers themselves and presents significant difficulties when it is translated into a foreign language, which implies mandatory rooting in the language norm of the translation language.

The basis of the energy potential of both novels is a dynamic fluctuation from the Norm (in the broadest sense of the term) to its vanguard or modernist negation, a scurrying from one to another level of the work texture, a transmuting passage through it, which results in the original text of the work. But in most cases, because of the disparate nature of languages, the translator must choose from two extremes (or even a multitude of teeming diverse manifestations) of the "quivering sense" ("sens tremble") - one of Simon's favorite aesthetic and rational attitudes - only one unambiguous side, characteristic, feature.

Just in such cases, comments are required that explain the acceptable-secret and explicit - ways of understanding the text, as well as all sorts of allusions, stylistic figures, puns created for a native speaker, connotative meanings of words that do not have parallels in the translation language. The result of this "philological translation" will be not so much the replacement of the original text with its translation, but rather their productive, often polemical, dialogue, which encourages the reader to go beyond the usual boundaries of his aesthetic expectations and wider - languages, traditions of literary translation and socio-cultural 
stereotypes.

In the practice of translation studies, critical analysis of specific translations is based, as a rule, "on an intuitive view of the genre-stylistic norm" (Kazakova, 2003; Marandi, \& Homayonnia, 2019). But returning to the Claude Simon's novels, we note that in relation to them, as well as many masterpieces of world literature, it is often difficult, and in some ones it is hardly necessary. In this light, interpretative commentary on the most complex and ambiguous fragments of the original text based on the proposed translation (translation options) is acceptable and even mandatory (especially in the framework of such a publication as "Literary Monuments", designed for a demanding and prepared reader, both a lover of literature and a specialist in its study).

The principal linguistic feature of the translation of Claude Simon's books, as well as other representatives of the French New Novel, is the need, unfortunately ignored by many translators, to convey their unusual treatment of grammar, vocabulary, stylistic registers, syntax (complex multi-page phrases without capital letters and most of the usual punctuation marks, unconventional use of the system of grammatical tenses, systematic play on the polysemy of words) of the French language, which is traditionally proud of its regularity, "clarity": "Ce qui n'est pas clair n'est pas français".

In order for the reader to understand these features adequately, the translator should, as it seems, offer in the comments an overview of the genesis and evolution of the novel: from Balzac to Proust, from the development of the matrix of the modern novel in the XIX century to its significant - up to the destruction -adjustment by the avant-gardists of the XX century. It is equally important to note for the reader of translation the fundamental differences in the perception of syntax and, more generally, grammar of the text by the French readers, as many phenomena of the Simon's text is particularly challenging for direct translation generated by the protest against this inert and extremely rationalized matrix of French grammar. Protest, but also play with it, often eludes the Russian-speaking reader due to a number of fundamental differences in languages.

The language of Claude Simon's novels, including the "The Flanders Road" and "The Invitation" discussed below, combines long ago noticed properties of the French language originally and paradoxically that were rejected by this writer at a superficial glance: emotional expressiveness and the desire for rational clarity and transparency, noted by the first grammarians (for example, D. Buur, a French grammarian and Jesuit of the XVII century, to whom the words quoted below belong): "the French are sharp and mobile by nature, irrepressible and passionate - they have a laconic and ensouled language, in which there is not a drop of languid bliss". As a Frenchman is considered to be more concise and less prone to hyperbole or metaphor than a Spaniard or an Italian, he will express himself in a more mature language, the queen of which is brevity" (Tourrette, 2017; 83). 
The following quotation mentions a number of narrative and poetic features of Claude Simon's books that make them difficult to understand in the original language and even more difficult for their adequate translation and further perception of the translated text by the reader, and much will depend on the "similarities and differences in the language pictures of the world" (Shatilova et al., 2018; Abolfathi, \& Taebi, 2019), of the original and translation languages. Unlike metaphors or similes, analogy, which is referred to in the quotation below - one of the methodological and aesthetic foundations of the Claude Simon's style - is much more difficult to be adequately transmitted by means of a foreign language, in our case Russian (especially in pure language level, tied to lexical and grammatical features of the French language), without reference to the capabilities of the "philological translation" (commentary, variance, explanations, deviations from standard Russian language). The composition of Claude Simon's novels is distinguished, at first glance, by the intertwining of different stories depicting different characters in different eras and places. The combination of diegetic heterogeneity often falls to the narrator-hero's share, in whose memory the matter of these incompatible stories is bounded. Moreover, the nature of the relations that unite these stories becomes clearer when referring to the concept of analogy, understood both as a mental device and as a poetic principle of composition. It is interesting that "the concept of analogy oscillates between two divergent and even antagonistic definitions. For our contemporaries, an analogy is a kind of fuzzy similarity, perhaps spectacular, but always deceptive. For the Ancients, on the contrary, it is a process of clear reasoning, governed by strict laws" (Michel, 2014; 193). Interestingly, the concept of analogy, "translation by analogy" is not allowed for obvious reasons when translating terminology, where they are allowed "to appeal only in exceptional cases - when there is no corresponding equivalent in the Russian language" (Pisarikhina, 2016 ; 82).

Summing up some results of my own experience of a translation of Claude Simon, one of the authors of this paper wrote in the review of the novel "The Grass" intended for foreign researchers and readers of Nobel laureate 1985: "Thus, I involve the reader in what Russian formalists, so dear top Simon, called debarment, opening in what seems to be normal and welladjusted, something strange, unusual, through which comes forth the true and new. The reader becomes a student in the Claude Simon's workshop, where the chaotic and bizarre are fraught with a rush to the world, "where everything is - order and beauty" (Vishnyakov, 2015; 118).

A practical illustration of the ideas of this paper can be the analysis of the experience of translating into Russian the works of one of the most complex authors of the French New Novel - Claude Simon. The material will be Elena Babun's translation of Simon's most famous novel "The Flanders Roads", a translation of the novel "The Grass" prepared for the "Literary Monuments" series, and a very unusual example of the translation of Simon's 1987 work "The Invitation" by three translators who did not know about the work of the other two and, consequently, found and made mistakes completely independently of each other. 
The translation of one of the most difficult to transmit by means of a foreign language novel by Claude Simon and wider - modern French literature - "The Flanders Roads" is performed at a fairly high level, especially in view of the ideological and socio-cultural situation of the Soviet Union in the 1980s. The translator tried to convey as accurately as possible the content of the novel (the usual for Simon, but exotic for Soviet literature mixture of Eros and Thanatos) and its formal features. Let us first look at how she managed to do the second. The most important features of this writer's style are: the unusual use of tenses (present and imparfait, first of all), verbal forms of participles and adverbs, which often destroy the usual hierarchy of relationships, becoming, along with verbs and nouns, completely autonomous and independent of them members of his "periods" (which are sometimes difficult to call sentences, because they may lack the beginning, end, and most punctuation marks), translating the action from "reality" with its mutually correlated perfective and imperfective tenses of verbs into a colloidal hybrid of fantasy and memory.

E. Babun, trying to "comb" the text, often replaces the present tense with imparfait, participles and adverbs with a verb in the present or in passé simple, which turns Simon's branded oniric descriptions into quite realistic ones, in the manner of Balzac or Zola. An example of such a "corrective translation" is the scene of the death of a fellow soldier of the main character Vack under German bullets, in which only two of the ten present participles are correctly transmitted, and the rest are replaced by verbs in the past and present tense. The translator's omission of the last word is no less significant in this fragment, a personal prepositional pronoun, which, despite the impossibility of using it in isolation from its verb, is used exactly this way: despite the fact that in Russian such a deviation from the requirements of school grammar looks much less heretical, the translator normalized it, giving completeness to what in the Simon's poetics is defiantly open and incomplete both the utterance itself and its form: see Illustration 1.

\section{Illustration 1}

Fragment of the translation of the novels "The Flanders Roads" and "The Invitation" by Claude Simon

Fragment of the original text: see "La Route des Flandres" (Duffy \& Duncan, 2002; 303).

“The Flanders Roads”, Elena Babun's translation, 1983: “[...]kak budto on vsyo eshchyo prodolzhal skakat' na kakom-to nevidimom Pegase kotoryj vzbryknuv perebrosil ego cherez golovu vynudiv takim obrazom vypolnit' vsyo v tom zhe zamedlennom tempe i tak skazat' na meste dvojnoe i ves'ma riskovannoe sal'to kotoroe on vskore pokazal mne vniz golovoj po prezhnemu s shiroko otkrytym rtom vsyo $\mathrm{v}$ tom zhe krike (ili sovete kotoryj on pytalsya prokrichat' mne) $\mathrm{v}$ etom bezmolvnom krike potom lezhashchim $\mathrm{v}$ vozduhe na spine kak lezhit $\mathrm{v}$ gamake otdyhayushchij dachnik svesiv nogi sprava i sleva two words are omitted v vertikal'nom polozhenii uzhe golovoj vverh $a$ nogi postepenno teryali prezhnyuyu poziciyu vsadnika i 
sdvinutye vmeste svisali uzhe parallel'no potom ego razvernulo na zhivot obe ruki vytyanulis' vperyod ladoni raskrylis' slovno on sobiralsya skhvatit' pojmat' chto-to chto nahodilos' na nekotorom ot nego rasstoyanii kak cirkovoj akrobat $\mathrm{v}$ tot mig kogda on visit ni za chto ne derzhas' mezhdu dvumya trapeciyami i telo ego ne podchineno zakonu zemnogo prityazheniya potom $\mathrm{v}$ konce koncov golova ego snova ochutilas' vnizu nogi razoshlis' v storony a ruki raskinulis' krestom budto on zhelal pregradit' mne put' no teper' polnost'yu nepodvizhnyj vlipshij $\mathrm{v}$ pridorozhnyj otkos ne shevelyas' bol'she i glyadya pryamo na menya na ego lice zastylo udivlyonno-glupoe vyrazhenie ya podumal Bednyaga Vak vsegda-to u nego byl idiotskij vid no sejchas eshchyo bolee idiotskij chem obychno, / a word is omitted / [...]" (Duffy \& Duncan, 2002; 462-463).

The facts of self-censorship in relation to the content (which would never be allowed by a translator who adheres to the "philological translation" discussed in this paper) will be briefly considered in the erotic passages from the novel by Claude Simon. The translator completely omitted the erotic segments of the text (and with them also the Simon's paradoxical arguments on a variety of topics, which has always been his bright feature), appearing in the original text of the novel on pages 325-326, 372-373, 385. None of the 12 uses of the verb pénétrer, almost always accompanied by erotic connotations, is preserved in the translation. A description of the classic for all times and peoples drawing "oval divided in two" (p. 385) and a whole fragment about "two hieroglyphs of two primary elements" is omitted (p. 395-396).

A comparison of three translations of Simon's small text "The Invitation" made by translators, and none of them was aware of the work of the other two, almost in the same period, in the late 1980s (see Illustration 2), can be no less indicative for the topic of this paper. The main features of these translations are highlighted in the text of the illustration. And here it is characteristic that the translation by a professional philologist, an employee of the Institute of World Literature of the Russian Academy of Sciences Marina Arias-Vikhil should be recognized as the most successful and adequate, which is quite close to what is called in this paper "philological translation" - not only in essential adequate to the original transmission of the content of the text, but also on the formal level, which in this example is quantitative, but very important from the different points of view, criteria of volume of original text and translation and that is difficult (and often not even set as a goal) identities in number and functions of used punctuation. According to both these criteria, the translation of M. Arias-Vikhil is ahead of the other two.

These examples show clearly that only a competent and conscious approach to solving many subtle, implicit, complex linguistic, socio-cultural or aesthetic problems can provide adequate translation of complex texts, which include many works of classical and modern literature. It is in such cases that it becomes possible and even necessary to use the type that was at the center of this paper - philological translation. 


\section{Illustration 2}

Fragment of the original text: see "L'Invitation"(Duffy \& Duncan, 2002; 384).

"The Invitation", translated by Natalia Gorbanevskaya, Marina Arias-Vikhil, Ekaterina Lyamina.

Natalia Gorbanevskaya, 1989 (937 symbols. 31 punctuation mark): "V techenie vsego vremeni, kotoroe oni proveli u podnozh'ya ispolinskoj gory, oni neprestanno slyshali gornuyu reku. Ona byla zdes', nevidimaya, skrytaya $v$ ushchel'e, gde rosli topolya, nedostizhimaya, po tu storonu vysochennoj reshyotki, kotoraya okruzhala park s roskoshnymi dachami, i po eyo shumu, neustannomu, yarostnomu shipen'yu, mozhno bylo eyo voobrazit', penistuyu, s burlyashchej vodoj, /a word is omitted/ beskonechno skatyvayushchuyusya, probivshuyusya gdeto iz kakogo-to fantasticheskogo lednika i nakonec vyryvayushchuyusya na ravninu (ravnina, issushennaya step', gde ej predstoit ischeznut') posle togo, kak ona preodolela tesnye gorloviny, perekatilas' s poroga na porog, vsyo eshchyo yarostnaya,_otfyrkivayas', potryasaya svoej vodyanoj, ischerna-serebryanoj grivoj, bez konca perepletaya svoi tekuchie kosy, kipya tak, slovno ot staroj chudovishchnoj gory bezostanovochno donosilsya $v$ vide gluhogo mychaniya golos kakogo-to chudishcha, kakogo-to izdevatel'skogo orakula, ravnodushnogo, hranyashchego nekuyu tajnu bez tajny" (Duffy \& Duncan, 2002; 323).

Marina Arias-Vikhil, 1988 (quoted from a manuscript edited by A.G. Vishnyakov, 821 symbols, 28 punctuation marks): "Vsyo vremya, poka oni nahodilis' u podnozhiya gornoj gromady, oni /a word is omitted/ slyshali shum potoka. On shumel sovsem ryadom, nevidimyj, pryachas' v nizine, zarosshej topolyami, nedosyagaemyj za nepristupnoj ogradoj, okruzhavshej park s roskoshnymi rezidenciyami, i po ego shumu, neskonchaemomu burleniyu, shipeniyu mozhno bylo voobrazit' ego penyashchimsya, stremitel'no nesushchimsya vniz, vzdymaya vody, istekayushchie otkuda-to iz /a word is omitted/ fantasticheskogo lednika, i vybirayushchimsya, nakonec, na ravninu (zasushlivuyu step', v kotoroj emu suzhdeno zateryat'sya), projdya skvoz' uzkie ushchel'ya, /a word is omitted/ yarostno obrushivayas' /the past infinitive is replaced by the past participle/ vodopadami, /a word is omitted/ potryasaya vodyanymi grebnyami, chernoserebristymi, perepletaya bez konca svoi vodyanye kosy, burlya, budto s drevnej, vnushayushchej uzhas gory neprestanno donosilos' gluhoe rychanie nevedomogo chudovishcha, nasmeshlivogo, ravnodushnogo orakula, vladeyushchego nekimi tajnami bez tajny".

Ekaterina Lyamina, 2003 (947 symbols, 35 punctuation marks): "V prodolzhenie vsego vremeni, provedyonnogo imi u podnozhiya uzhasnoj gory, oni ne perestavali slyshat' potok. On byl tam, nevidimyj, skrytyj v nizine, gde rosli topolya, nedosyagaemyj iz-za vysokoj i krepkoj reshyotki, kotoroj byl obnesyon park s roskoshnymi rezidenciyami, i, slushaya ego shum, 
nemolchnyj i zhivoj, mozhno bylo predstavit', kak on bez ustali nesyot svoi vody vniz, penyas' i podprygivaya, vyhodya na svet neizvestno gde, iz kakogo-nibud' fantasticheskogo lednika, i nakonec ustremlyaetsya na ravninu (ravnina, issohshaya step', gde emu predstoyalo ischeznut'), preodolev tesniny ushchelij, sprygnuv /the past infinitive is replaced by the past participle/ s ustupa odnim, zatem drugim vodopadom, eshchyo serdityj, pleshchushchijsya, /a word is omitted/ vstryahivayushchij zavitkami vodyanoj grivy, chyorno-serebryanyj, bez konca perepletayushchij svoi tekuchie kosy, burlyashchij, kak esli by iz nedr drevnej i strashnoj gory nepreryvno donosilsya gluhoj ryk - golos kakogo-to chudovishcha, kakogo-to nasmeshlivogo, ravnodushnogo orakula, znayushchego tajnu, v kotoroj net tajny" (Duffy \& Duncan, 2002: 59).

\section{Illustration 3.}

Comparative table of translation features of the three translators of the C. Simon's work "The Invitation".

\begin{tabular}{|c|c|c|c|}
\hline $\begin{array}{l}\text { The author of the translation } \\
\text { Translation evaluation features } \\
\text { and criteria }\end{array}$ & N.Gorbanevskaya & M.Arias-Vikhil & E.Lyamina \\
\hline Year and the translation status & 1989, published & $\begin{array}{l}1988, \text { the } \\
\text { manuscript is } \\
\text { prepared for } \\
\text { printing }\end{array}$ & $\begin{array}{l}2003, \\
\text { published }\end{array}$ \\
\hline $\begin{array}{l}\text { Number of symbols compared to the } \\
\text { original }\end{array}$ & $937 / 988$ & $821 / 988$ & $947 / 988$ \\
\hline $\begin{array}{l}\text { Number of punctuation marks } \\
\text { compared to the original }\end{array}$ & $31 / 24$ & $28 / 24$ & $35 / 24$ \\
\hline Unsuccessful (incorrect) options & 7 & 4 & 14 \\
\hline Omitting (missing) words & 1 & 5 & 2 \\
\hline Successful translation options & 9 & 8 & 2 \\
\hline $\begin{array}{l}\text { Adequacy of translation in } \\
\text { accordance with the above criteria }\end{array}$ & High & Maximum & Sufficient \\
\hline
\end{tabular}

\section{Conclusions}

As we can see, with more or less successful prevention of the almost inevitable increase in volume when translating from analytical French into synthetic Russian (especially such a complex text as a novel by Claude Simon), all four translators - consciously or unconsciously, due to established traditions - on the one hand, normalized (most often clarifying, simplifying 
the original) the text of the translation, on the other hand - weighed down (trying to make the text more "accessible") its grammatical and syntactic, primarily syntactic design, which found expression in increasing the variety and number of punctuation marks. The philological translation considers these and similar "translation solutions" unacceptable, striving for what can be called "understanding of the text" of the original, as true as possible, if necessary, multi variant and annotated, the translation of its artistic and semantic features. The linguistic aspect of this problem is considered in the article by N.A. Filatova "On the history of Russian-French language contacts: biographical notes” (Duffy \& Duncan, 2002).

Based on all of the above, we will try to offer a definition (or rather, due to the small development of this topic and the specifics of its subject - a systematizing description) of a philological translation, without fear of the inevitable exaggeration of schematics, in many of its operating characteristics are not approval, and denial that characterize the phenomenon, not narrowing it with a priori attitudes that are fundamentally important for such object of study as a literary text, which is intended to be a linguistic translation of a literary text. For greater clarity, we will resort to the form of abstracts.

1. Philological translation means referring to a text that is classical in its richness, complexity, and significance in world literature.

2. The commercial potential of translating such a text is not obvious and requires the publisher to give up short-term profitability, the translator to give up routine work that fits into a predetermined time frame, and the reader to give up focusing on nonproblematic (non-conflict, uncomplicated), linear, one-time reading/consumption of the book in favor of rereading/savoring

3. Priority of the translated text over the translation is recognized in this case as undisputed, which leads to several consequences in the choice of translation tactics and strategy: to abandon the attempt to hide the secondary nature of the read text, to the resultant abandonment of "taming", the assimilation of alien and not essential in the form and content of the translated text and the rejection of prescriptively in favor of descriptively (no matter how deeply the translator would dive into the world of the translated text, he will never reach the author's scale of the perception of the text, which means that the hypothetical description in his work should be systematically preferred to the categorical prescription), to the refusal to focus only on the singlecultural reader and publisher; to the priority of loyalty in any difficult situations to the alien, different and strange writer and his text.

4. A direct and unavoidable consequence of the above is a greater or lesser weighting and complication of the translation text in comparison with both the original and the usual models of the translated text, which is possible only with a "pact of trust" between the translator, the reader and the publisher. The reader and publisher come 
to the signing of this pact with their own requirements and capabilities, which, although they should be taken into account by the translator, should not have a decisive impact on him. As far as the translator is concerned, the basis of such a pact is the highest possible level of understanding of the translated text, the poetics and problems of the translated author in this place and at this moment.

5. The translator must not only have all the usual professional competencies, but also be in constant contact with experts in the work of the translated author, ideally - be one of them.

6. The latter implies the need for the institute of scientific editing and reference-critical apparatus that accompanies the text of the translation in order to mitigate its inevitable rigid one-dimensionality in the conditions of entering a foreign language and foreign cultural environment. The reference and critical apparatus of publishing a philological translation is designed to avoid both overly dry and detailed factual and scientific problems, and overly emotional subjectivity, essays of newspaper and magazine criticism.

7. The essential task of this device is to compensate for the inevitable - various and multi- level- losses of the original text in translation, which can be done in a variety of ways: from simply pointing out the loss and explaining the reasons for it to trying to indicate the lost in an informative or artistic way, giving the reader the opportunity, if not to see, then at least to imagine the dynamic cosmogony of the original.

8. Occupying a relatively modest place in the hierarchy of scientific sources, this apparatus must, however, meet the strictest formal criteria of scientific discourse imposed on scientific publications, which does not exclude, but emphasizes its significant content, methodological and stylistic freedom, if not analogous, then congruent to the boundless and self-sufficient freedom inherent in the literary text.

\section{References}

Abolfathi, E., \& Taebi, P. (2019). Modern Analysis of Financial Statements: Pharmaceutical companies in Iran. Journal of management and accounting studies, 7(02), 19-23.

Charles, M. (2019). Le système, l'antisystème. Poetique, (1), 5-29.

Duffy, J. H., \& Duncan, A. (Eds.). (2002). Claude Simon: A retrospective. Oxford University Press.

Filatova N.A. (2019). On the history of Russian-French language contacts: biographical notes. Proceedings of the Volgograd State Pedagogical University. Linguistics. Scientific Journal. № 2 (135). Volgograd: VSPU, 2019. P. 175-181.

Kazakova, T. A. (2003). Teoriya perevoda (lingvisficheskiye aspekty)[Theory of Translation 
(Linguistic Aspects)]. St Petersburg, Soiuz Publ.

Marandi, M. R., \& Homayonnia, P. (2019). Effects and consequences of termination of contract in Iranian law. Journal of Social Sciences and Humanities Research, 7(02), 22-25.

Michel, C. (2014). Hommes-troncs, mille-pattes et moustaches en crocs. Poetique, 2, 193-210.

Pisarikhina, A. S. (2016). On the issue of pharmacoviglance terminology. Kazan science. Kazan, 2, 81-84.

Shatilova, L. M., Borisova, V. V., \& Kasatkina, O. A. (2018). Representation of the linguistic and cultural concept "lie" in the French and Russian language picture of the world. Opción: Revista de Ciencias Humanas y Sociales, 85, 257-276.

Tourrette, É. (2017). Pudeur de la langue française. Poétique, 181(1), 83-94. doi:10.3917/poeti.181.0083.

Vishnyakov, A. (2015). La jouissance d'une écriture novatrice. Traduire et éditer Claude Simon en russe, Cahiers Claude Simon [En ligne], 10 | 2015, mis en ligne le 22 septembre 2017, consulté le 20 juin 2020. URL : http://journals.openedition.org/ccs/953 ; DOI : https://doi.org/10.4000/ccs.953 